\title{
Selection of Beauveria bassiana (Bals.) Vuill. isolates for controlling Sitophilus zeamais (Mots.) (Coleoptera: Curculionidae)
}

\author{
Seleção de isolados de Beauveria bassiana (Bals.) Vuill. para o controle de \\ Sitophilus zeamais (Mots.) (Coleoptera: Curculionidae) \\ Vando Miossi Rondelli ${ }^{1}$, José Romário de Carvalho², Dirceu Pratissoli², \\ Ricardo Antonio Polanczyk ${ }^{3}$, João Rafael De Conte Carvalho de Alencar ${ }^{3}$, \\ Fernando Domingo Zinger ${ }^{2}$, Sara Maria Andrade Pereira ${ }^{2}$
}

\begin{abstract}
Sitophilus zeamais (Mots.) (Coleoptera: Curculionidae) is considered a major pest of maize, responsible for reducing grain quality and making the corn inappropriate for industrial use and human consumption. S. zeamais has been controlled exclusively with chemical products. The objective of this research was to select isolates of Beauveria bassiana (Bals.) Vuill. to control S. zeamais. Beetles were immersed in conidia suspensions of each isolate for five seconds and placed in a gerbox container with maize grains. In pathogenicity tests, the isolates that caused the highest mortality to the maize weevil were ESALQ-447 (68.0\%), CCA-UFES/ Bb-36 (57.3\%) and CCA-UFES/Bb-31 (51.3\%). ESALQ-447 was the most virulent, with an $\mathrm{LC}_{50}$ of $1.7 \times 10^{7}$ conidia/ml and shows promise for controlling maize weevils. These isolates of $B$. bassiana can be used as effective substitutes for conventional chemical control, normally carried out with phosphine. Further tests should be performed under field and semi-field conditions to develop an appropriate strategy for the use of this entomopathogen to manage $S$. zeamais.
\end{abstract}

Key words: maize weevil, microbial control, entomopathogenic fungus, stored grains.

\section{RESUMO}

Sitophilus zeamais (Mots.) (Coleoptera: Curculionidae) é considerado uma das principais pragas do milho, responsável pela redução da qualidade dos grãos, tornando-os impróprios para indústria e consumo humano. Para seu controle tem-se utilizado exclusivamente produtos químicos. Assim, o objetivo deste trabalho foi selecionar isolados de Beauveria bassiana (Bals.) Vuill. para o controle de S. zeamais. Besouros foram imersos em suspensões de conídios de cada isolado por cinco segundos e acondicionados em gerbox contendo grãos de milho. Nos testes de patogenicidade os isolados que causaram maior mortalidade confirmada ao gorgulho-do-milho foram ESALQ-447 (68,0\%), CCA-UFES/Bb-36 (57,3\%) e CCA-UFES/Bb-31 (51,3\%), sendo o primeiro mais virulento e promissor ao controle desta praga com $C L_{50}$ de $1,7 \times 10^{7}$ conídios $/ \mathrm{ml}$. A utilização desses isolados de $\mathrm{B}$. bassiana pode ser um substituto eficaz ao controle convencional realizado, normalmente, com fosfina. Testes devem ser feitos em campo e semi-campo para elaboração de uma estratégia adequada para utilização deste entomopatógeno no manejo de $\mathrm{S}$. zeamais.

Palavras chave: gorgulho-do-milho, controle microbiano, fungo entomopatogênico, grãos armazenados.

\section{Introduction}

Ten percent of total grain production is lost to insect pests, causing serious economic losses (Trevizan \& Baptista, 2000). If grain storage pest control is not improved, efforts to increase grain production could be fruitless (Fontes et al., 2003).
The maize weevil, Sitophilus zeamais (Mots.) (Coleoptera: Curculionidae), is considered one of the most important corn pests (Gallo et al., 2002), responsible for a large amount of grain damage; it reduces grain quality and in turn makes grains inappropriate for industrial use and human consumption (Caneppele et al., 2003). The most frequently used

1 Universidade Federal Rural de Pernambuco, Departamento de Agronomia/Entomologia, Dom Manoel de Medeiros, s/n, Dois Irmãos, 52171-900, Recife, PE, Brazil.

2 Universidade Federal do Espírito Santo, Centro de Ciências Agrárias, Departamento de Produção Vegetal, Alto Universitário, s/n, C. Postal-16, 29500-000, Alegre, ES, Brazil.

3 Universidade Estadual Paulista, Departamento de Fitossanidade/Entomologia, Via Prof. Paulo Donatto Castellani, s/n, 14884900, Jaboticabal, SP, Brazil. E-mail: rapolanc@fcav.unesp.br

Fecha de Recepción: 5 Octubre, 2010.

Fecha de Aceptación: 6 Septiembre, 2012. 
method to control the maize weevil is to purge the insect from grains with phosphine (aluminum phosphide or magnesium phosphide) (Nakakita et al., 1974; Potrich et al., 2006). However, this product has an elevated persistence in the food supply and environment, in addition to being toxic to those applying the product and promoting the selection of resistant insect populations (Collins et al., 2002; Daglish, 2004; Potrich et al., 2006).

Thus it is necessary to develop new control methods, such as biological control using entomopathogenic fungi, which show great potential as control agents against Sitophilus spp. The mode of action of entomopathogenic fungi against pests occurs primarily through their contact with conidia (Alves \& Lecuona, 1998; Potrich et al., 2006), which show an elevated capacity for horizontal dispersal, being able to be transported by diverse means over large distances, forming foci of dissemination (Alves, 1998b; Castrillo et al., 2005).

These agents are not toxic to humans or other animals, do not select for resistant pest populations, do not cause environmental pollution and do not cause damage to the grain mass (Alves, 1998a; Pereira et al., 1998). However, the action of entomopathogenic fungi is slow and adequate conditions are needed to maintain their viability and pathogenicity (Lord, 2005).

Because of the vast genetic variability shown by entomopathogenic fungi, various studies have emphasized the necessity of bioassays to screen for isolates that are highly virulent, persistent and with a high reproductive capacity (Alves, 1998b; Silva et al., 2003; Neves \& Hirose, 2005). Thus there is increased potential for the use of entomopathogenic fungi as microbiological insecticides (Dal Bello $e t$ al., 2001; Potrich et al., 2006).

Among entomopathogenic fungi, Beauveria bassiana (Bals.) Vuill. possesses the greatest potential for controlling pest insects that damage stored grains (Moino Júnior \& Alves, 1997; Kassa et al., 2002; Potrich et al., 2006). The objective of this study was to select isolates of $B$. bassiana to control S. zeamais.

\section{Materials and Methods}

The experiment was conducted in the Entomology sector at the Núcleo de Desenvolvimento Científico e Tecnológico em Manejo Fitossanitário (NUDEMAFI), at the Centro de Ciências Agrárias of the Universidade Federal do Espírito Santo (CCA-UFES) in Alegre, Espírito Santo, Brazil, and consisted of the following steps:

\section{Maize weevil rearing}

Insect strains from the stocks of the Entomology Laboratory at NUDEMAFI were tested. These insects were reared in maize kernels in glass containers (12 $\mathrm{cm}$ diameter and $17 \mathrm{~cm}$ height) with a perforated top to allow gas exchange. The containers were kept in a climatized room with a temperature of $25 \pm 2{ }^{\circ} \mathrm{C}$, relative humidity of $70 \pm 10 \%$, and 12 hour photophase (Coitinho et al., 2006).

\section{Obtaining and maintenance of isolates}

The study tested eleven isolates of the fungus B. bassiana (extracted from agricultural soils) and the standard isolate ESALQ-447, registered and selected for the control of other pests (Alves, 1998b) (Table 1). These isolates were stored in the entomopathogen stocks at NUDEMAFI in plastic Eppendorf-type tubes containing potato, dextrose, agar, yeast extract and tetracycline antibiotic (PDAY+A) at $8{ }^{\circ} \mathrm{C}$. The fungi were incubated for 7 days on Petri dishes $(10 \times 2.0 \mathrm{~cm})$ containing PDAY+A medium. Coffee borer beetles, Hypothenemus hampei (Ferr.) (Coleoptera: Scolytidae), were inoculated with the fungus, and after conidiogenesis the fungi were reisolated in Petri dishes with PDAY+A medium. The fungi were then incubated for another 7 days (Leite et al., 2003).

Conidia viability was monitored by the germination method (Silva et al., 2003), in which conidia were considered viable when they showed a germination rate above $90 \%$. The fungus was grown in a climatized chamber at a temperature of $26 \pm 1{ }^{\circ} \mathrm{C}$, relative humidity of $70 \pm 10 \%$, and 12-hour photophase.

\section{Pathogenicity evaluation}

The fungi were multiplied again for 10 days, using a Drigalski handle to produce conidia. Fungal suspensions were obtained by adding $10 \mathrm{ml}$ of sterilized distilled water plus Tween ${ }^{\circledR} 80$ adhesive spreader $(0.05 \%)(\mathrm{SDW}+\mathrm{S})$ to plates containing the culture medium and the fungus. After rapid manual shaking and scraping with a sterilized soft bristle brush, they were filtered in sterilized gauze, 
Table 1. Origins and hosts of Beauveria bassiana isolates tested in Sitophilus zeamais.

\begin{tabular}{lll}
\hline Isolate & Source & Host or substrate \\
\hline CCA-UFES/Bb-31 & Ibatiba-ES & Soil, coffee plants \\
CCA-UFES/Bb-32 & Ibatiba-ES & Soil, coffee plants \\
CCA-UFES/Bb-33 & Ibatiba-ES & Soil, coffee plants \\
CCA-UFES/Bb-34 & Ibatiba-ES & Soil, coffee plants \\
CCA-UFES/Bb-35 & Alegre-ES & Soil \\
CCA-UFES/Bb-36 & São José do Calçado-ES & Soil, coffee plants \\
CCA-UFES/Bb-37 & São José do Calçado-ES & Soil, coffee plants \\
CCA-UFES/Bb-38 & São José do Calçado-ES & Soil, coffee plants \\
CCA-UFES/Bb-39 & São José do Calçado-ES & Soil, coffee plants \\
CCA-UFES/Bb-40 & Alege-ES & Soil, coffee plants \\
CCA-UFES/Bb-41 & Ibatiba-ES & Soil, coffee plants \\
ESALQ-447 & Cuiabá-MS & Solenopsis invicta (Buren)
\end{tabular}

quantified in a Neubauer chamber and adjusted to a concentration of $1 \times 10^{8}$ conidia/ml (Silva et al., 2003).

S. zeamais adults between the ages of 1 and 30 days were immersed for 5 seconds in conidia suspensions of each isolate (housed in glass tubes), then removed by filtration in Voil-type tissue and placed in plastic gerbox containers $(6.3 \mathrm{~cm}$ in diameter and $2.2 \mathrm{~cm}$ in height) containing one corn kernel per insect. The control treatment consisted of the immersion of insects in SDW+S. The containers were placed in a climatized chamber at a temperature of $26 \pm 1{ }^{\circ} \mathrm{C}$, relative humidity of $70 \pm$ $10 \%$ and a 12 hour light cycle.

Evaluations were performed daily for a period of 10 days by verifying the number of dead insects. Those that died were transferred to humid chambers to verify the cause of death. A completely randomized design (CRD) was used with thirteen treatments and five repetitions containing 30 insects in each repetition, totaling 150 insects per treatment.

\section{Virulence evaluation}

The isolates which caused the highest confirmed mortality rate in $S$. zeamais adults were selected for the virulence evaluation phase. These isolates were newly multiplied for the production of conidia. Suspensions were prepared at concentrations of $1 \times 10^{4}, 1 \times 10^{5}, 1 \times 10^{6}, 1 \times 10^{7}$ and $1 \times 10^{8}$ conidia/ml for each isolate, in addition to the control using SDW+S. The suspension preparation, the inoculation of insects with fungal isolates, and the evaluations used the same procedures described for the evaluation of pathogenicity. Five repetitions were used per treatment with 20 insects in each repetition, totaling 100 insects per concentration for each isolate.

\section{Statistical Analysis}

The corrected mortality was calculated with the formula of Abbott (1925). Corrected and confirmed mortality data were checked for normality by the Shapiro-Wilk test, and for homogeneity of variance by the Bartlett test. Data were subjected to analysis of variance and means were compared by the Scott-Knott test using a significance level of $5 \%$. The lethal concentration $\left(\mathrm{LC}_{50}\right)$ was calculated using probit analysis.

\section{Results and Discussion}

\section{Pathogenicity evaluation}

All isolates were pathogenic in S. zeamais adults. The percentages of corrected mortality varied from $72.8 \%$ to $19.7 \%$ and the confirmed mortality varied from $68.0 \%$ to $20.7 \%$ (Table 2). The control group had $2.0 \%$ mortality. The isolate ESALQ-447 showed the highest percentage of corrected mortality. The confirmed mortality of isolates ESALQ-447, CCA-UFES/Bb-36 and CCA-UFES/Bb-31 did not show significant differences, with $69.8 \%, 57.3 \%$, and $51.3 \%$, respectively. These isolates could be potential control agents for the maize weevil, since entomopathogenic fungi are considered effective when they show mortality values above $40 \%$ (Lecuona et al., 1996).

Using the same inoculation technique with the fungi B. bassiana and Metarhizium anisopliae (Metsch.) Sorok., Kassa et al. (2002) were able to 
Table 2. Corrected and confirmed mortality (\%) of adult maize weevils, Sitophilus zeamais, subjected to different isolates of Beauveria bassiana, 10 days after inoculation (temperature: $26 \pm 1{ }^{\circ} \mathrm{C}, \mathrm{RH}: 70 \pm 10 \%$, and 12-hour photophase).

\begin{tabular}{lcc}
\hline \multirow{2}{*}{ Isolate } & \multicolumn{2}{c}{ Mortality $^{(1)}$} \\
\cline { 2 - 3 } & Corrected & Confirmed \\
\hline ESALQ-447 & $72.8 \pm 8.40 \mathrm{a}$ & $68.0 \pm 7.79 \mathrm{a}$ \\
CCA-UFES/Bb-36 & $56.5 \pm 5.53 \mathrm{~b}$ & $57.3 \pm 5.42 \mathrm{a}$ \\
CCA-UFES/Bb-31 & $51.7 \pm 6.12 \mathrm{~b}$ & $51.3 \pm 5.54 \mathrm{a}$ \\
CCA-UFES/Bb-38 & $43.5 \pm 9.95 \mathrm{c}$ & $44.0 \pm 9.39 \mathrm{~b}$ \\
CCA-UFES/Bb-35 & $41.5 \pm 7.25 \mathrm{c}$ & $42.7 \pm 7.10 \mathrm{~b}$ \\
CCA-UFES/Bb-32 & $40.8 \pm 6.14 \mathrm{c}$ & $42.0 \pm 6.02 \mathrm{~b}$ \\
CCA-UFES/Bb-34 & $38.1 \pm 5.10 \mathrm{c}$ & $39.3 \pm 4.99 \mathrm{~b}$ \\
CCA-UFES/Bb-37 & $38.1 \pm 7.33 \mathrm{c}$ & $39.3 \pm 7.18 \mathrm{~b}$ \\
CCA-UFES/Bb-41 & $33.3 \pm 2.76 \mathrm{c}$ & $34.7 \pm 2.71 \mathrm{~b}$ \\
CCA-UFES/Bb-40 & $29.3 \pm 7.33 \mathrm{c}$ & $30.0 \pm 6.91 \mathrm{~b}$ \\
CCA-UFES/Bb-33 & $24.5 \pm 4.74 \mathrm{c}$ & $26.0 \pm 4.64 \mathrm{~b}$ \\
CCA-UFES/Bb-39 & $19.7 \pm 3.97 \mathrm{c}$ & $20.7 \pm 3.71 \mathrm{~b}$ \\
CV (2) $(\%)$ & 35.61 & 33.63 \\
\hline
\end{tabular}

(1) Means ( \pm SE) followed by the same letter in the columns do not differ by the Scott-Knott test at $5 \%$ probability.

(2) Coefficient of variation.

elevate the mortality rate of S. zeamais from $92 \%$ to $100 \%$. Potrich et al. (2006) evaluated thirteen isolates of B. bassiana at a concentration of $1 \times 10^{9}$ conidia/ml with $S$. zeamais adults immersed in a $1 \mathrm{ml}$ suspension of conidia and shaken for $10 \mathrm{sec}-$ onds, with confirmed mortality varying from $8.3 \%$ to $98.3 \%$. However, at a concentration of $1 \times 10^{8}$ conidia/ml for 10 days, the best isolates (Unioeste 4, Unioeste 39 and ESALQ-643), showed confirmed mortality of $48.3 \%, 45.0 \%$ and $45.0 \%$, respectively, while the isolate ESALQ-447 showed a mortality rate of $68.0 \%$ (Table 2).

The mortality of the control group was $2.0 \%$. This affected negatively the results of corrected mortality. Thus for some isolates for which all deaths were confirmed, e.g. CCA-UFES/Bb-36 and CCA-UFES/Bb-38, the confirmed mortality was slightly greater than the corrected mortality.

\section{Evaluation of virulence}

The lowest lethal concentration $\left(\mathrm{LC}_{50}\right)$ was observed using the isolate ESALQ-447 (1.7 x 107 conidia/ml), followed by the isolates CCA-UFES/ Bb-31 $\left(7.9 \times 10^{7}\right.$ conidia/ml) and CCA-UFES/ Bb-36 (1.5 x $10^{8}$ conidia $\left./ \mathrm{ml}\right)$; however, the $\mathrm{LC}_{50}$ of these last isolates did not differ within a $95 \%$ confidence interval (Table 3). A high $\mathrm{LC}_{50}$ value indicates less toxicity; therefore a less toxic isolate needs a greater concentration of conidia to cause the same insect mortality as a more toxic isolate.

The isolate $B$. bassiana PPRC-HH showed high virulence to $S$. zeamais beetles immersed in suspended conidia, with an $\mathrm{LC}_{50}$ of $2.04 \times 10^{6}$ conidia/ml (Kassa et al., 2002). By contrast, isolate 604 B. bassiana, inoculated with rice grains, showed an $\mathrm{LC}_{50}$ of $0.0067 \mathrm{~g}$ of conidia per $100 \mathrm{~g}$ of rice after ten days of exposure (Moino Júnior \& Alves, 1997).

The ratios of $\mathrm{LC}_{50}$ toxicity for isolates CCAUFES/Bb-36 and ESALQ-447; CCA-UFES/Bb-31 and ESALQ-447; and CCA-UFES/Bb-36 and CCAUFES/Bb-31 were 8.8, 4.6 and 1.9, respectively. This indicates that the isolate CCA-UFES/Bb-36 should

Table 3. Slope of the concentration-mortality curves (mean \pm standard error) and lethal concentration $\left(\mathrm{LC}_{50}\right)$ of Beauveria bassiana on adult maize weevils, Sitophilus zeamais (temperature: $26 \pm 1{ }^{\circ} \mathrm{C}, \mathrm{RH}: 70 \pm 10 \%$, and 12-hour photophase).

\begin{tabular}{lccccc}
\hline Isolate & $\mathrm{n}^{(1)}$ & Slope $\pm \mathrm{SE}^{(2)}$ & $\mathrm{LC}_{50}(\mathrm{conidia} / \mathrm{ml})(95 \% \mathrm{CI})^{(3)}$ & $\mathrm{df}^{(4)}$ & $\chi^{2(5)}$ \\
\hline ESALQ-447 & 500 & $0.73 \pm 0.089$ & $\begin{array}{c}1.7 \times 10^{7} \\
\left(1.0 \times 10^{7}-3.0 \times 10^{7}\right)\end{array}$ & 3 & 2.1 \\
CCA-UFES/Bb-31 & 500 & $0.44 \pm 0.061$ & $\begin{array}{c}7.9 \times 10^{7} \\
\left(3.2 \times 10^{7}-2.9 \times 10^{8}\right)\end{array}$ & 3 & 2.4 \\
CCA-UFES/Bb-36 & 500 & $0.46 \pm 0.066$ & $\left(5.7 \times 10^{7}-6.7 \times 10^{8}\right)$ & 3 & 2.9 \\
& & & &
\end{tabular}

(1) Number of insects used in the test.

(2) Standard error.

(3) Confidence interval of the $\mathrm{CL}_{50}$ at $95 \%$ probability.

(4) Number of degrees of freedom.

(5) Chi-square value. 
be applied at a concentration 8.8 times that of the isolate ESALQ-447 to cause the same mortality of adult $S$. zeamais.

The mortality concentration curve of the ESALQ-447 isolate presented the steepest slope (0.73), while the slopes of the other isolates $(0.44$ for CCA-UFES/Bb-31 and 0.46 for CCA-UFES/ $\mathrm{Bb}-36)$ were not as steep and were similar to each other (Table 3). High slope values of curves indicate that small variations in fungal concentration promote large variation in the mortality of adult $S$. zeamais.

In the field, environmental conditions are the principal limitation for using entomopathogenic fungi for the control of insect pests (Alves, 1998a). For example, solar radiation prevents the development of conidia (Fernandes et al., 2007). Fungi such as B. bassiana need temperatures between 23 and $28^{\circ} \mathrm{C}$ with $90 \%$ relative humidity for adequate development (Alves, 1998b). Conditions under grain storage are more stable (Moino Júnior \& Alves, 1997) and grains are not exposed to solar radiataion, thus such conditions are favorable for the use of this method to control storage grain pests.
Therefore, microbial control with B. bassiana can be an effective substitute for conventional control, which is normally done with phosphine. However, studies should be carried out under the field and semi-field conditions to develop an adequate strategy to control S. zeamais with entomopathogenic fungi.

\section{Conclusion}

The isolate ESALQ-447 was the most virulent for adult $S$. zeamais; however, the isolates originating in soils also showed satisfactory mortality rates for this pest.

\section{Acknowledgements}

The authors acknowledge the support given in the form of research grants by the agencies $\mathrm{CNPq}$ (Conselho Nacional de Desenvolvimento Científico e Tecnológico), FINEP (Financiadora de Estudos e Projetos) and FAPES (Fundação de Amparo à Pesquisa do Espírito Santo).

\section{Literature Cited}

Abbott, W.S.

1925 A method of computing the effectiveness of an insecticide. Journal of Economic Entomology, v. 18, pp. 265-267.

Alves, S.B.

1998a Patologia e controle microbiano: vantagens e desvantagens. In: Alves, S.B. (ed.). Controle microbiano de insetos. Piracicaba: FEALQ, 1163 p.

Alves, S.B

1998b Fungos entomopatogênicos. In: Alves, S.B. (ed.). Controle microbiano de insetos. Piracicaba: FEALQ, 1163 p.

Alves, S.B.; Lecuona, R.E.

1998 Epizootiologia aplicada ao controle microbiano de insetos. In: Alves, S.B. (ed.). Controle microbiano de insetos. Piracicaba: FEALQ, 1163 p.

Caneppele, M.A.B.; Caneppele, C.; Lazzari, F.A.; Lazzari, S.M.N. 2003 Correlation between the infestation level of Sitophilus zeamais Motschulsky, 1855 (Coleoptera, Curculionidae) and quality factors of stored corn, Zea mays L. (Poaceae). Revista Brasileira de Entomologia, v. 47, n. 4, pp. 625-630.

Castrillo, L.A.; Roberts, D.W.; Vandenberg, J.D.

2005 The fungal past, present, and future: Germination, ramification, and reproduction. Journal of Economic Entomology, v. 89, n. 1, pp. 46-56.

Coitinho, R.L.B. De C.; Oliveira, J.V. De; Gondim Junior, M.G.C.; Câmara, C.A.G. Da.

2006 Efeito residual de inseticidas naturais no controle de Sitophilus zeamais Mots. em milho armazenado. Caatinga, v. 19 , n. 2, pp. 183-191.
Collins, P.J.; Daglish, G.J.; Bengston, M.; Lambkin, T.M.; Pavic, H. 2002 Genetics of resistance to phosphine in Rhyzopertha dominica (Coleoptera: Bostrichidae). Journal of Economic Entomology, v. 95, n. 4, pp. 862-869.

Daglish, G.J.

2004 Effect of exposure period on degree of dominance of phosphine resistance in adults of Rhyzopertha dominica (Coleoptera: Bostrichidae) and Sitophilus oryzae (Coleoptera: Curculionidae). Pest Management Science, v. 60, n. 8, pp. 822-826.

Dal Bello, G.; Padin, S.; López Lastra, C.; Fabrizio, M.

2001 Laboratory evalution of chemical-biological control of the rice weevil (Sitophilus oryzae L.) in stored grains. Journal of Stored Products Research, v. 37, n. 1, pp. 77-84.

Fernandes, E.K.K.; Rangel, D.E.N.; Moraes, A.M.L.; Bittencourt, V.R.E.P.; Roberts, D.W.

2007 Variability in tolerance to UV-B radiation among Beauveria spp. isolates. Journal of Invertebrate Pathology, v. 96, n. 3, pp. 237-243.

Fontes, L.S.; Almeida Filho, A.J.; Arthur, V.

2003 Daños causados por Sitophilus oryzae (Linné, 1763) e Sitophilus zeamais Motschulsky, 1855 (Coleoptera: Curculionidae) em cultivares de arroz (Oryza sativa L.). Arquivos do Instituto Biológico, v. 70, n. 3, pp. 303-307.

Gallo, D.; Nakano, O.; Silveira Neto, S.; Carvalho, R.P.L.; Batista, G.C.; Berti Filho, E.; Parra, J.R.P.; Zucchi, R.A.; Alves, S.B.; Vendramin, J.D.

2002 Entomologia agrícola. Piracicaba: FEALQ, 920 p. 
Kassa, A.; Zimmermann, G.; Stephan, D.; Vidal, S. 2002 Susceptibility of Sitophilus zeamais (Motsch.) (Coleoptera: Curculionidae) and Prostephanus truncatus (Horn) (Coleoptera: Bostrichidae) to entomopathogenic fungi from Ethiopia. Biocontrol Science and Technology, v. 12 , n. 6 , pp. $727-736$.

Lecuona, R.E.; Tigano, M.S.; Diaz, B.M.

1996 Characterization and pathogenicity of Beauveria bassiana against Diatraea saccharalis (F.) (Lepidoptera; Pyralidae) in Argentina. Anais da Sociedade Entomológica do Brasil, v. 25 , n. 2, pp. 299-307.

Leite, L.G.; Batista Filho, A.; Almeida, J.E.M.; Alves, S.B. 2003 Controle de qualidade. In: Leite, L.G.; Batista Filho, A.; Almeida, J.E.M.; Alves, S.B. Produção de fungos entomopatogênicos (Eds). Ribeirão Preto: Alexandre de Sene Pinto, $92 \mathrm{p}$.

Lord, J.C.

2005 Low humidity, moderate temperature, and desiccant dust favor efficacy of Beauveria bassiana (Hyphomycetes: Moniliales) for the lesser grain borer, Rhyzopertha dominica (Coleoptera: Bruchidae). Biological Control, v. 34, n. 2, pp. 180-186.

Moino Júnior, A; Alves, S.B.

1997 Determinação de concentrações de Beauveria bassiana (Bals.) Vuill. para o controle de insetos-pragas de grãos armazenados. Anais da Sociedade Entomológica do Brasil, v. 26, n. 1 , pp. $15-20$.
Nakakita, H.; Saito, T.; Iyatomi, K.

1974 Effect of phosphine on the respiration of adult Sitophilus zeamais Motsch. (Coleoptera, Curculionidae). Journal of Stored Products Research, v. 10, n. 2, pp. 87-92.

Neves, P.M.O.J.; Hirose, E.

2005 Seleção de isolados de Beauveria bassiana para o controle biológico da Broca-do-café, Hypothenemus hampei (Ferrari) (Coleoptera: Scolytidae). Neotropical Entomology, v. 34 , n. 1, pp. 77-82.

Pereira, R.M.; Alves, S.B.; Reis, P.R.

1998 Segurança no emprego de entomopatógenos. In: Alves, S.B. (ed.). Controle microbiano de insetos. Piracicaba: FEALQ, $1163 \mathrm{p}$

Potrich, M.; Alves, L.F.A.; Mertz, N.R.; Silva, E.R.L. 2006 Avaliação de Beauveria bassiana (Bals.) Vuill. e Metarhizium anisopliae (Metsch.) Sorok. para controle de Sitophilus zeamais (Coleoptera: Curculionidae). BioAssay, v. 1, n. 12, pp. 1-9.

Silva, V.C.A.; Barros, R.; Marques, E.J.; Torres, J.B.

2003 Suscetibilidade de Plutella xylostella (L.) (Lepidoptera: Plutellidae) aos fungos Beauveria bassiana (Bals.) Vuill. e Metarhizium anisopliae (Metsch.) Sorok. Neotropical Entomology, v. 32, n. 4, pp. 653-658.

Trevizan, L.R.P.; Baptista, G.C.

2000 Resíduos de deltametrina em grãos de trigo e em seus produtos processados, determinados por cromatografia gasosa. Scientia Agricola, v. 57, n. 2, pp. 199-203. 